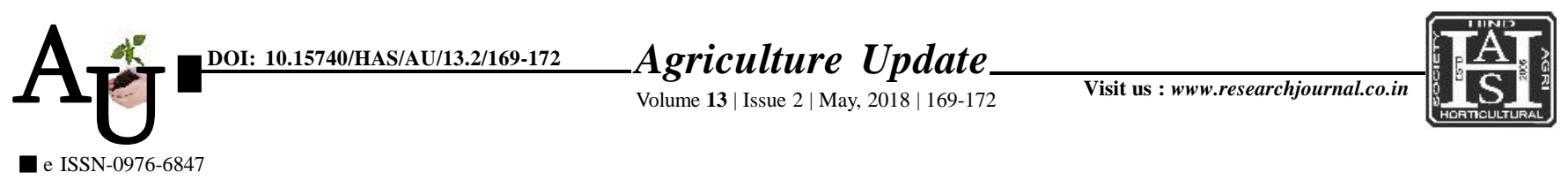

\title{
Rевевсн автісів: Perception of women leaders towards holding the leadership for gender upliftment
}

\begin{tabular}{l} 
Article C \\
\hline Received : \\
30.11.2017; \\
Revised : \\
22.03.2018; \\
Accepted : \\
07.04.2018
\end{tabular}

KEY Words:

Leadership, Perception, Women leaders

\section{Author for correspondence :}

Jyoti Kumari Department of Agricultural Extension, College of Agriculture, Indira Gandhi Krishi Vishwavidyalaya, Raipur (C.G.) India Email : jyoti.ext2710@ gmail.com

See end of the article for authors' affiliations

\section{Jyoti Kumari and M.L. Sharma}

SUMMARY : Women are being sharing the half of the population of our country. This study has focused towards the reason behind the involvement of women towards leadership. Constitutions have tried to evict the gender discrimination. 50 per cent reservation of women representatives of Panchayats had blommed the engagement of both the genders equally. The women representatives (Sarpanchs) have several reasons behind to put themselves in this agenda. Here, 112 women Sarpanchs were selected to provide the reason and perception of them towards leadership. The analysis reveals that majority ( $45.53 \%)$ of had participated in the leadership due to reservation for women. Also the 83.03 per cent of them had perception regarding improvement of social status of women among the society. This could be further promoted by encouraging women in every field of leadership.

How to cite this article : Kumari, Jyoti and Sharma, M.L. (2018). Perception of women leaders towards holding the leadership for gender upliftment. Agric. Update, 13(2): 169-172; DOI : 10.15740/HAS/AU/13.2/169-172. Copyright@2018: Hind Agri-Horticultural Society. 